\title{
An Environmentally Friendly Soil Improvement Technology with Microorganism
}

\author{
Daehyeon Kim* and Kyungho Park ${ }^{\dagger}$
}

\begin{abstract}
Cement or lime is generally used to improve the strength of soil. However, bacteria were utilized to produce cementation of loose soils in this study. The microo rganism called Bacillus, and $\mathrm{CaCl}_{2}$ was introduced into loose sand and soft silt and $\mathrm{CaCO}_{3}$ in the voids of soil particles were produced, leading to cementation of soil particles. In this study, loose sand and soft silt typically encountered in Korea were bio-treated with 3 types of bacteria concentration. The cementation (or calcite precipitation) in the soil particles induced by the high concentration bacteria treatment was investigated at 7 days after curing. Based on the results of Scanning Electron Microscope (SEM) tests and EDX analyses, high concentration bacteria treatment for loose sand was observed to produce noticeable amount of $\mathrm{CaCO}_{3}$, implying a significant cementation of soil particles. It was observed that higher calcium carbonate depositions were observed in poorly graded distribution as compared to well graded distribution. In addition, effectiveness of biogrouting has also been found to be feasible by bio-treatment without any cementing agent.
\end{abstract}

Keywords : Bacteria, Soil, Biotreatment, Cementation, Biogrouting, Cementing agent

\section{Introduction}

Bio-treated soil improvement technology has recently been suggested (Mitchell and Santamarina 2005) and attempted by several researchers (Dejong et al. 2006, Whiffin et al. 2007, Paassen et al. 2010, Kim et al. 2012, Park and Kim 2012; 2013).

Although a number of bacteria can be found in the soil, Bacillus pasteurii has been commonly used in producing microbial cementation of soil particles. This is because Bacillus pasteurii uses urea as an energy source and produces ammonia, which increases $\mathrm{pH}$ in the neighboring environment, causing $\mathrm{Ca}^{2+}$ and $\mathrm{CO}_{3}{ }^{2-}$ to precipitate as $\mathrm{CaCO}_{3}$ (Stocks-Fisher 1999, Bachmeier et al. 2002, Dejong et al. 2010).

The principle of microbially induced cementation of soil

\footnotetext{
Corresponding author: Department of Civil Engineering, Chosun University, Korea E-mail : munhakng@nate.com

* Department of Civil Engineering, Chosun University, Korea

(C) The Korean Society for Railway 2013

http://dx.doi.org/10.7782/IJR.2013.6.3.090
}

is as follows:

As shown in equation 1), bacteria eats urea and $\mathrm{CO}_{3}{ }^{2-}$ and $2 \mathrm{NH}_{4}{ }^{+}$are produced through hydrolysis. Then, calcium carbonate (calcite) is precipitated(see equation 2 ).

$$
\begin{aligned}
& \mathrm{CO}\left(\mathrm{NH}_{2}\right)_{2}+2 \mathrm{H}_{2} \mathrm{O} \text { Urease reaction } \\
& \mathrm{CO}_{3}{ }^{2-}+2 \mathrm{NH}_{4}^{+}
\end{aligned}
$$

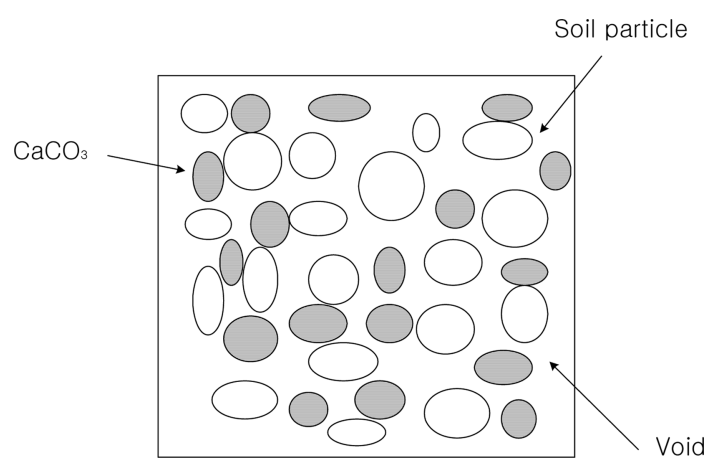

Fig. 1 Cementation of soil particles through calcite precipitation 


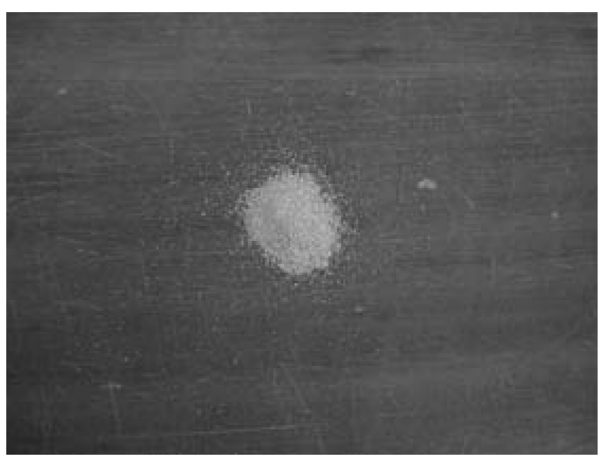

Fig. 2 No treatment sand (at 7 days after curing)

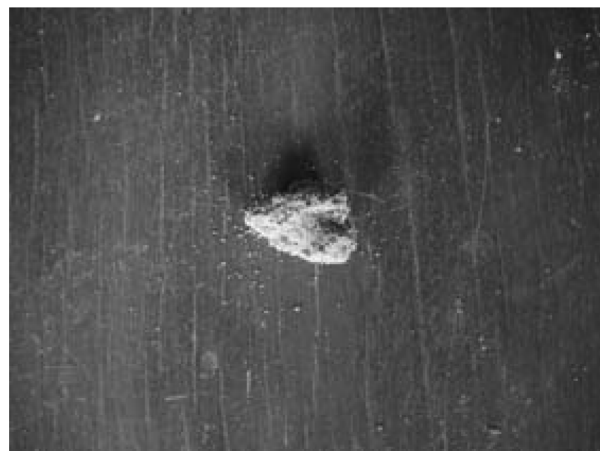

Fig. 3 High concentration bacteria treatment (at 7 days after curing)

Fig. 1 shows a schematic of how calcite precipitation $\left(\mathrm{CaCO}_{3}\right)$ fills the voids of soft soil and creates cementation of soil particles.

\section{Findigs of Cementation Using Microorganism}

\subsection{Cementation of soils}

Figs. 2 and 3 compare the difference in the cementation for two sand specimens(which has been presented at Kim et al.(2011): one for No- Bacteria-Treatment and another for High-Concentration-Bacteria-Treatment.

The specimens were oven-dried for 24 hours at a temperature of $110^{\circ}$ in Celsius, seven days after curing. As shown in Figs. 2 and 3, no indication of cementation between particles is observed in the No-Treatment sand, while a clear cementation between particles is observed in the High-Concentration-Bacteria-Treatment sand.

\subsection{Effect of ground conditions}

The mixing ratio of silty sand specimen used in this study was 1:1 for the microbial solution and the calcium chloride solution as shown in Table 3. Relative density
Table 1. Specimen Mixing Ratio Depending on the

\begin{tabular}{ccccc}
\multicolumn{6}{c}{ Level of Compaction } \\
\hline \hline Specimen & $\begin{array}{c}\text { Relative } \\
\text { Compaction } \\
(\%)\end{array}$ & $\begin{array}{c}\text { Soil } \\
(\mathrm{g})\end{array}$ & $\begin{array}{c}\text { Calcium } \\
\text { Chloride } \\
\text { Solution }(\mathrm{ml})\end{array}$ & $\begin{array}{c}\text { Microbial } \\
\text { Solution } \\
(\mathrm{ml})\end{array}$ \\
\hline \multirow{3}{*}{ SM } & 60 & 223 & 10 & 10 \\
\cline { 2 - 5 } & 75 & 279.3 & 11.5 & 11.5 \\
\cline { 2 - 5 } & 90 & 297.4 & 13 & 13 \\
\hline
\end{tabular}

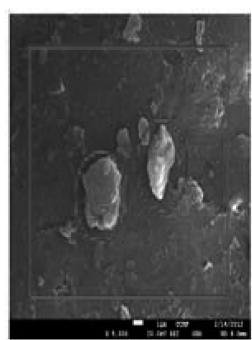

(a)

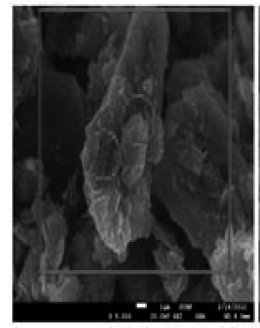

(d)

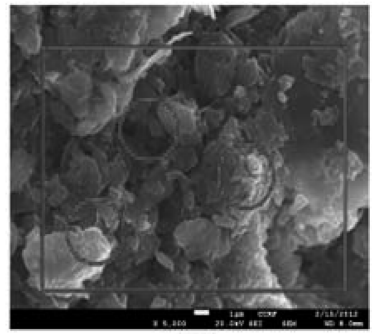

(g)

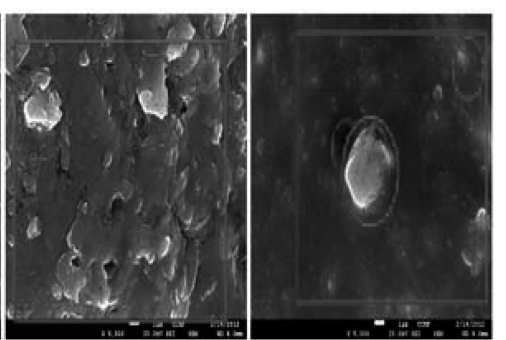

(c)

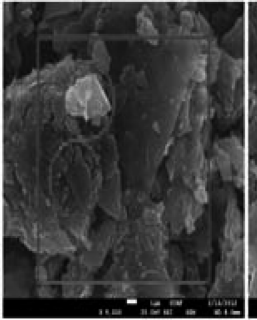

(e)

(f)
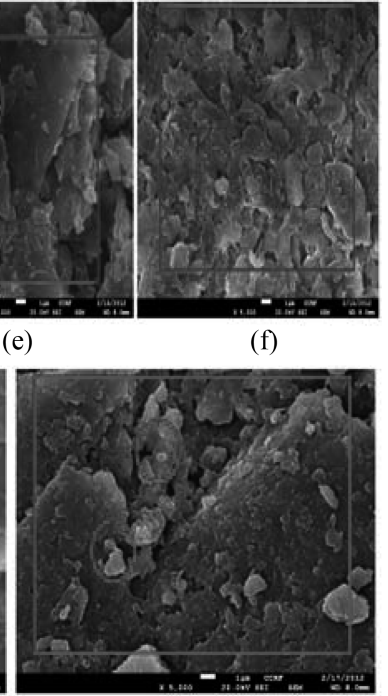

(h)

Fig. 4 SEM results for (a) Dr 40\%, (b) Dr 60\%, (c) Dr 80\%, (d) Relative compaction $60 \%$, (e) Relative compaction $75 \%$, (f) Relative compaction 90\%, (g) Well graded, (h) Poorly graded

was set to $60 \%, 75 \%$ and $90 \%$ for different ground conditions to conduct the laboratory test so as to identify the level of created calcium carbonates depending on the level of compaction.

SEM produces 2-dimensional data which is similar to 3dimensional images and allows depositions created on the surface of soil particles to be accurately observed. The result of SEM analysis by the magnification of 5000 times for the tested specimen is shown in Fig. 4. It was identified that the portion with the highest $\mathrm{Ca}$ number was circular, and calcium carbonate depositions by microbes were 
observed. The portions used in analyzing the result in EDX analysis is represented as a square to reveal the $\mathrm{Ca}$ content in the relevant portion.

EDX belongs to the electronic microscope family and is analysis equipment in which a scanning electron microscope is combined with an energy dispersive x-ray spectrometer, and used to analyze which elements are included in a small amount of sample. Therefore, it was intended to identify the level of calcium carbonate depositions with the $\mathrm{Ca}$ element content to be identified.

In the comparison of $\mathrm{Ca}$ content, the relative density of $60 \%$ exhibited the highest calcium carbonate deposition. This illustrates that, if voids are too loose, soil particles are not reasonably combined, to result in the low level of calcium carbonate depositions.

The highest calcium carbonate deposition was exhibited at $90 \%$ of relative compaction, which is the first reaction soils other than sand, and it was identified that higher compaction levels contributed to higher calcium carbonate depositions. However, the difference is insignificant. Other soils than sand should be further studied.

With respect to well graded distribution and poorly graded distribution, EDX analysis revealed lots of calcium carbonate depositions in poorly graded distribution. The result was that, because uniform voids were created in poorly graded soil, it was accordingly identified that higher calcium carbonate depositions were observed in poorly graded distribution as compared to well graded distribution.

\subsection{Applicability of biogrouting}

Soil cementation by microbes is achieved by: creating carbon dioxide $\left(\mathrm{CO}_{2}\right)$ and ammonium $\left(\mathrm{NH}_{4}\right)$ through urease (enzyme for hydrolysis of urea) in the microbial solution which is a new environment-friendly material to produce carbonates $\left(\mathrm{HCO}_{3}\right)$; and mixing calcium chloride solution $\left(\mathrm{CaCl}_{2}\right)$ which is a reactive solution to enable the calcium carbonate $\left(\mathrm{CaCO}_{3}\right)$ to deposit in the voids of soil to firmly cement soil particles. An exemplary method of cementing the soft ground is the injection technique. Instead of using cement or liquid, the environmentfriendly grout material of microbes is used to inject the microbial solution and the reactive solution to integrate microbes with grouting technique to produce a bio-grout material which is an environment-friendly material.

Studies on bio-grouting are still at the experimental stage. The microbes for bio-grouting are used in various fields in addition to the geotechnical engineering. For biogrouting, the grouting technique used in geotechnical engineering is integrated with bio-grout materials to enable microbes to permeate into voids between particles and

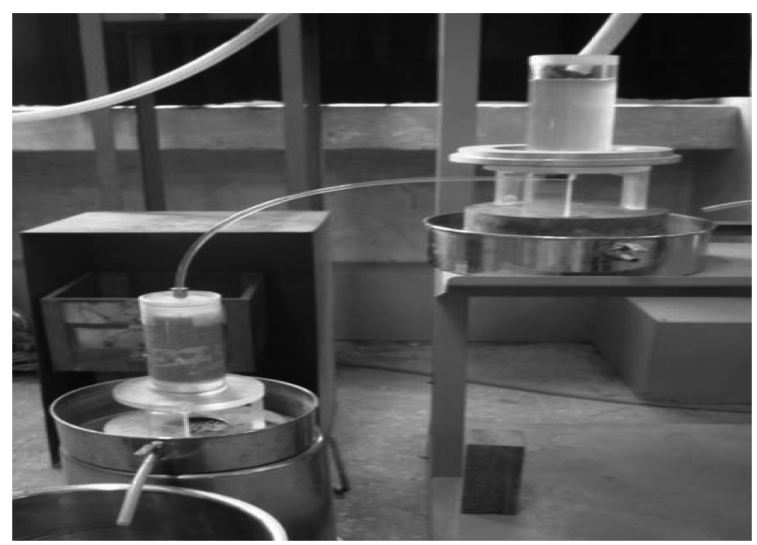

Fig. 5 Permeability test with cylindrical model device $(5 \mathrm{~cm} \times 12 \mathrm{~cm})$

then to fill the voids between grounds with calcium carbonate depositions more closely. This method achieves the effect of increasing strength and preventing the flow of water. In this study, we identified the effect of preventing the flow of water in the soft ground with bio-grout material through the permeability test. The added reactive solution was calcium chloride of $0.75 \mathrm{Mol}$ for microbial deposition. The microbes (KCTC 3558) B. pasteurii passed through voids between the soil particles when injected, but they are enlarged to be $0.06 \mathrm{~mm}-0.1 \mathrm{~mm}$ in size, approximately 20 times larger if mixed with the reactive solution and calcium carbonate deposition occurs. For this reason, it is necessary to have enough voids to allow microbes to freely move when the microbes grow through the microbial reaction.

\subsubsection{Effect of biogrouting on hydraulic conductivity}

A closed cylinder model device $(5 \mathrm{~cm} \times 12 \mathrm{~cm})$ was produced, other than the injection hole and the drainage way on top and on the bottom for smooth injection and drainage. A porous plate was installed on the bottom of the device to avoid the solution in which the microbes are injected and water to flow out. The specimen was put and the porous plate was installed to avoid flowing only through a given part. As shown in the following Figure, a water head difference was made. Fig. 5 shows the cylindrical model device and the process of injecting the microbial solution.

In the permeability test, the non-treated sand specimen exhibited very high permeability of approximately $2.27 \times 10^{-2}$ $(\mathrm{cm} / \mathrm{s})$. The normal-concentration treated specimen exhibited the permeability of approximately $6.30 \times 10^{-3}(\mathrm{~cm} / \mathrm{s})$, approximately $30 \%$ higher than the non-treated specimen. This implies that was achieved by the fine calcium carbonate particles deposited in voids between particles. 
Table 2 Results of permeability test for sand

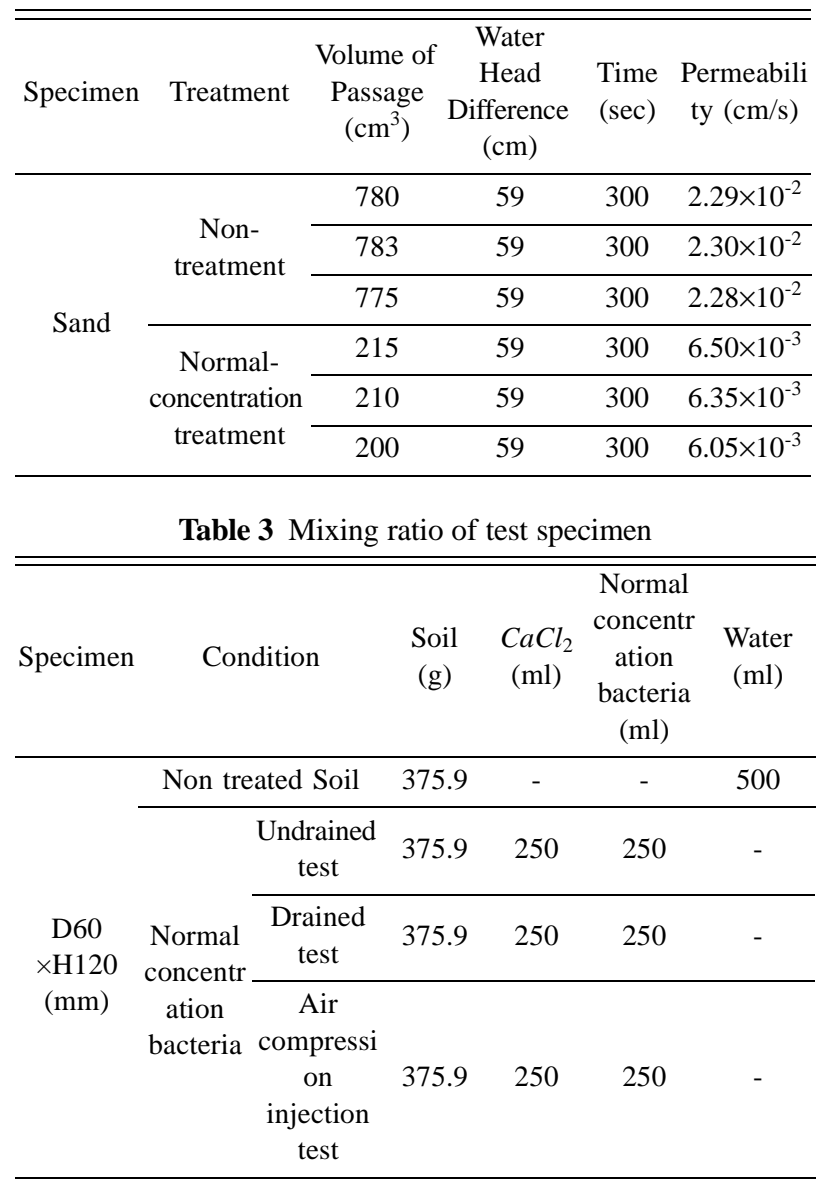

It was identified that the non-treated sandy silt specimen exhibited a low permeability of approximately $4.52 \times$ $10^{-4}(\mathrm{~cm} / \mathrm{s})$ as shown in Table 2 . In the case of normal treatment, the permeability was approximately $1.57 \times 10^{-4}$ $(\mathrm{cm} / \mathrm{s})$, approximately $35 \%$ higher than non-treated specimen, which is a high effect of reducing the permeability. It was identified that reducing the permeability was made by the fine calcium carbonate particles deposited in voids between particles.

\subsubsection{Effect of biogrouting on the strength of soil}

Table 3 shows the mixing ratio of specimens for different types of injection methods such as injection with syringe (drained and undrained), injection with air-compressor. In the injection with syringe, the same amount of bacteria and Calcium chloride were used. A total of $250 \mathrm{ml}$ was injected for five days $(25 \mathrm{ml} /$ each injection and twice a day), while in the injection with air-compressor, a total of $250 \mathrm{ml}$ was injected one time at a pressure of $0.5 \mathrm{kPa}$.

Fig. 6(a) and 6(b) shows the process of air-compressor

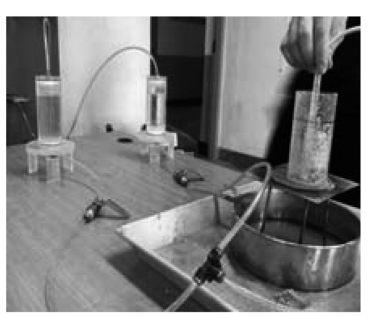

(a)

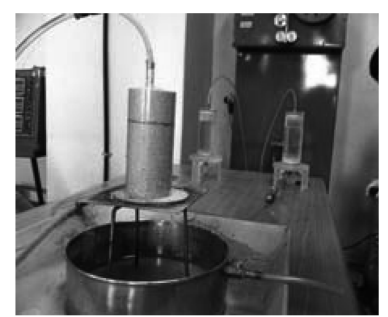

(b)
Fig. 6 (a) Air compressor injection,

(b) Process of Biogrouting test

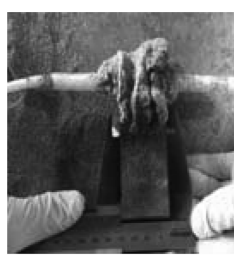

(a)

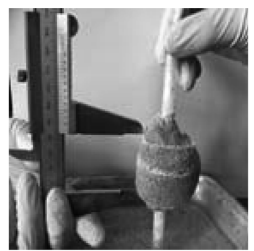

(b)

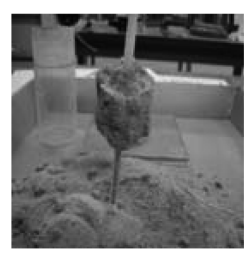

(c)
Fig. 7 Test result (a) Undrained test, (b) Drained test, (c) Air compressor injection test

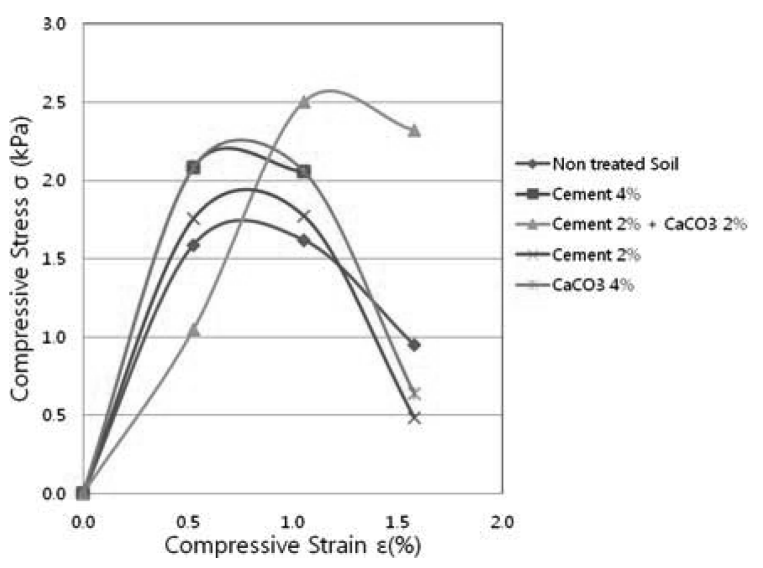

Fig. 8 Compressive strength with different mix

injection.

Fig. 7 shows the results of the cementation for each injection method. The thicknesses of cementation with undrained test, drained test and air-compressor injection test are $3.5 \mathrm{~cm}, 4.5$ and $5.4 \mathrm{~cm}$, respectively. The compressive strengths of undrained test, drained test, air-compressor injection test are $80 \mathrm{kPa}, 100 \mathrm{kPa}$ and $150 \mathrm{kPa}$, respectively. The reason why the air-compressor injection yields the largest cementation thickness and the highest compressive strength is that the injection pressure was done at a constant rate and infiltration of the solution was in a stable manner, resulting in enhanced cementation in the air-compressor injection. 
In order to evaluate the effectiveness of the treatment with microorganism, different treatment methods were attempted. Fig. 8 compares the unconfined compressive strength for different treatment methods such as nontreated soil, cement $4 \%$, cement $2 \%+\mathrm{CaCO}_{3} 2 \%$, cement $2 \%$ and $\mathrm{CaCO}_{3} 2 \%$. Note that the unconfined compressive strength was measured 3 days after mixing. As shown from Fig. 8, the unconfined compressive strengths of nontreated soil, cement $4 \%$, cement $2 \%$, cement $2 \%+\mathrm{CaCO}_{3}$ $2 \%$, cement $2 \%$ and $\mathrm{CaCO}_{3} 2 \%$ are $175 \mathrm{kPa}, 195 \mathrm{kPa}$, $220 \mathrm{kPa}, 255 \mathrm{kPa}$ and $230 \mathrm{kPa}$, respectively. Based on the test results, it is noted that the strength of cement $2 \%+\mathrm{CaCO}_{3} 2 \%$ is higher than that of cement $2 \%$. This implies that bio-treatment with microorganism is found to be feasible in the soil improvement, leading to reduction in the use of cement.

\section{Conclusions}

Based on the results of the study, the following conclusions can be drawn.

1. A clear cementation between particles is observed in the High-Concentration-Bacteria-Treatment sand.

2. Based on the SEM analyses and EDX analyses, the feasibility of cementation for loose sand with bacteria treatment is confirmed both quantitatively and qualitatively.

3. The normal-concentration treated specimen exhibited a permeability of $6.30 \times 10^{-3}(\mathrm{~cm} / \mathrm{s})$, which is approximately $30 \%$ of reduction in permeability. This proves that the microbial cementation is effective in reducing the flow of water in the soil.

4. Based on the test results, it is noted that the strength of cement $2 \%+\mathrm{CaCO}_{3} 2 \%$ is higher than that of cement $2 \%$. This implies that bio-treatment with microorganism is found to be feasible in the soil improvement, leading to reduction in the use of cement.

\section{Acknowledgments}

This research was supported by Basic Science Research Program through the National Research Foundation of Korea(NRF) funded by the Ministry of Science, ICT and Future Planning(NRF-2013R1A1A1AO5010106).

\section{References}

1. Bachmeier, K. L., Williams, A. E., Warmington, J. R., Bang, S. S. (2002). "Urease Activity in Microbiologically-induced Calcite Precipitation,” Journal of Biotechnology, Vol. 93, pp. 171-181.

2. Deong, J. T., Fritzges, M. B., Nüsslein, K. (2006). "Microbially Induced Cementation to Control Sand Response to Undrained Shear," Journal of Geotechnical and Geoenvironmental Engineering, Vol. 132, pp. 1381-1392.

3. Dejong, J. T., Mortensen, B. M., Martinez, B. C., Nelson, D. C. (2010). "Bio-mediated Soil Improvement," Journal of Ecological Engineering, Vol. 36, pp. 197-210.

4. Kim, D. H., Kim, H. C., Park, K. H. (2011). "Cementation of Soft Ground Using Bacteria," Korea Patent 10-1030761, pp.1-47.

5. Kim, D. H., Kim, H. C., Park, K. H., Lee, Y. H. (2012). "Effect of Microbial Treatment Methods on Biogrout," Journal of Korean Geo-Environmental Society, Vol. 13, pp. 5157.

6. Kim, D. H., Park, K. H., Kim, S. W., Mun, S. H. (2012). "A Novel Approach to Induce Cementation of Loose Soils," Advanced Science Letters, Vol. 9, pp. 545-550.

7. Kim, D. H., Park, K. H. (2013). "Injection Effect of Biogrout for Soft Ground," Advanced Science Letters, Vol. 19, pp. 468-472.

8. Mitchell, J. K., Santamarina, J. C. (2005). "Biological Considerations in Geotechnical Engineering," Journal of Geotechnical and Geoenvironmental Engineering, Vol. 131, pp. 1222-1233.

9. Paassen, L. A., Ghose, R., Linden, T. J. M., Star, W. R. L., Loosdrecht, M. C. M. (2010). "Quantifying Biomediated Ground Improvement by Ureolysis," Journal of Geotechnical and Geoenvironmental Engineering, Vol. 136, pp. 17211728.

10. Park, K. H., Kim, D. H. (2012). "Verification of Calcium Carbonate by Cementation of Silt and Sand using Bacteria," Jounal of Korean Geotechnical Society, Vol. 28, pp. 53-61.

11. Park, K. H., Kim, D. H. (2013). "Strength and Effectiveness of Grouting of Sand Treated with Bacteria," Jounal of Korean Geotechnical Society, Vol. 29, pp. 65-73.

12. Stocks-Fisher, S., Galinat, J. K., Bang, S. S. (1999). "Microbiological Precipitation of $\mathrm{CaCO}_{3}$," Soil Biology and Biochemistry, Vol. 31, pp. 1563-1571.

13. Whiffin, V. S., Paassen, L. A., Harkes, M. P. (2007). "Microbial Carbonate Precipitation as a Soil Improvement Technique," Geomicrobiology Journal, Vol. 24, pp. 1-7. 